J. Perinat. Med. 16 (1988) 305

\section{Improving perinatal outcome through data management: the design of the small area analysis system}

\author{
Jeffrey B. Gould, Nandita Mahajan, and Miguel Lucero \\ Maternal and Child Health Program, School of Public Health, University of \\ California Berkeley, California, U.S.A.
}

\section{Introduction}

Optimal utilization of resources to improve perinatal health requires information. Information on which to base health planning and allocation decisions and information that can be used to evaluate the outcome of planning and allocation decisions. The improved perinatal outcome data management system (IPODM) was developed by the Maternal and Child Health Program, University of California - Berkeley, School of Public Health under contracts \#84-84088 and \#8586955 to the State of California Department of Health Services, Maternal and Child Health Branch. IPODM consists of 1) a collection of health related observations or data bases and 2) a methodology to manipulate, analyze, and display this data in ways that "improve our understanding of problems and issues, as well as of the relative utility of the choices we face [10]".

IPODM is designed to facilitate small area analysis $[1,4,8]$ and enable local health managers and physicians to analyze census based sociodemographic data and vital statistics based perinatal data. Beginning at the census tract and/or zip code level, the data can then be built up into larger geographic areas. At both the local and the state level, the system facilitates the analysis of perinatal need and outcome by ethnicity, sociodemographic status, age, and geography. Although IPODM does not contain health facilities/resources databases, the system has been structured to allow for their easy inclusion in a future implementation.

\section{Curriculum vitae}

JEFFREY GOULD, M.D., $M . P . H$. received his $M . D$. in 1965 from the University of Rochester and his $\mathrm{Ma}$ ster of Public Health from the University of California in Berkeley. Dr. GouLD is Associate Profesor and Deputy Director of Maternal and Child Health, University of California, Berkeley, School of Public Health, Maternal and Child Health Program.

\section{Requirements}

In designing the improved pregnancy outcome data management system (IPODM) we first developed five key specifications:

1) The system should be interactive and suitable for the health manager with little computer experience.

2) The system should be based on standard elements and operating environments so as to be transportable to a variety of sites.

3) The system should be accessible via modem for "on site" analysis. 
4) The system should have the ability to build datasets using census and vital statistics variables and be easily expandable in terms of adding more variables and incorporating new datasets.

5). The basic building block should be the census tract and/or the zip code and the system should allow easy aggregation of these units into larger geographic areas.

The rationale behind each of these requirements will now be briefly discussed.

\subsection{Interactive system}

Beginning in the early 1980's there has been a transfer of Maternal and Child Health $(\mathrm{MCH})$ authority and activities from the federal to the local level [5]. While this has the advantage of enabling local needs assessment and program development, the trade off has been a decrease in the level of federal funds that could be brought to bear on $\mathrm{MCH}$ problems. An important goal of IPODM is to provide local health planners and practitioners with a tool that will facilitate and optimize their work. The use of an interactive format makes it possible for managers with little/ or no mainframe computer experience to generate, manipulate, and display large amounts of complex data that is specific to their needs. An interactive system eliminates the typical data acquisition loop: manager describes analytic problem to computer data analyst, manager waits in line with other projects for job to be completed, manager schedules a meeting to review output with data specialist, manager revises problem to explore an interesting finding and/or clarify something from the original job specification, manager waits in line with other projects for revised/extended job to be completed, etc. By eliminating the traditional "out of house" data analysis loop IPODM's interactive format greatly facilitates decision making at the local level.

\subsection{A system based on standard elements}

There may be something to be said for exotic, one off systems that are custom tailored. Unfortunately these systems are often custom tailored to the requirements and interests of the architects rather than the end user. Furthermore exotic systems can be difficult to maintain when "start up funds", and the system's creators are no longer available. IPODM was designed for an IBM-CMS [9] environment. We use REXX [2] for the interactive command structures and SAS [6] for building and manipulating data bases. These decisions were based on the availability and popularity of IBM mainframes and SAS at the local, state, and federal levels, the reliability of these components, and the large pool of personnel who are able to work with (i. e. initialize, trouble shoot, maintain) this type of system. The use of standard elements optimizes productivity by minimizing maintenance and operational costs, and allows the system to be suitable for installation in a variety of operating sites.

\subsection{Modem access}

An important advance in computer technology has been the ability of a stand free terminal to communicate with a remote mainframe computer via ordinary telephone lines. The "modem" (modulator/demodulator) is a device that makes this communication possible and allows data and commands to be input and results output over great distances.

The IPODM system was designed to be accessed by terminal and parallel printer via modem. At the completion of any analysis results can be seen on the terminal screen and outputed on a parallel printer, bringing all of IPODM's capabilities directly into the health manager's office. Although not every office has a terminal, printer, modem set up; we are rapidly approaching the point where most local health managers have office based microcomputing capability. To take advantage of this, IPODM supports communications between the mainframe system and MS DOS [7] microcomputers. Using the Personal Computer (P. C.) as a dumb terminal one can create an IPODM database on the remote mainframe and then receive or "down load" this database on the local microcomputer. Customized reports, and special graphics presentations can then be prepared on the local microcomputer.

\subsection{Expandability}

The scope of health management decisions that can be supported by an information system is defined by the scope of the data maintained by the system. In order to be efficient one must limit the number of variables to those that have a dem- 
onstrated utility or a high probability of being useful. However, the value of any particular variable is dynamic and depends upon the relationships between the variable and certain aspects of health. Over time science discovers new relationships between sociodemographic, environmental, biologic factors, and health. Over time the structures of populations and health delivery systems also evolve making it impossible to preselect all of the variables that would be needed over a five to ten year health planning/management cycle. An effective information system must be designed to easily incorporate new variables and new databases. IPODM is conceived as a health information system with sociodemographic and perinatal data bases in place. The future addition of SAS databases on other aspects of health such as provider location, facility utilization, environment hazard levels, for example, has been anticipated in the system's design.

\subsection{Small area analytic capability}

Large area "summary" statistics such as the neonatal mortality rate for the United States give broad overviews with respect to national and regional issues but often fail to reflect the needs of specific populations living in defined geographic areas. When the summary statistic is "bad" there is little doubt that a significant problem exists. Unfortunately, when the statistic is "good" there may still be areas with significant gaps in health outcome. Even at a smaller geographical level there are many examples of counties whose statistics are not "bad" enough to qualify for state supported programmatic assistance yet have large populations in need of these specialized programs. A pragmatic rationale for decentralization of needs assessment and program development is based on the epidemiologic reality that the United States in the 1980's resembles a patchwork quilt more than a melting pot. Analysis by small area is important because health needs and programs have specific geographic distributions and catchments. The task of the health manager is to identify and match the distribution of need with the distribution of services. IPODM uses the zip code and the census tract as basic analytic building blocks. The system allows data to be obtained for every tract (or zip), for specific groupings of tracts (zips), and for all tracts (zips) combined. The ability to view various areas with respect to sociodemographic composition and perinatal status and to easily combine these areas into groupings representing for example neighborhoods, catchments for visiting nursing teams, health service areas, perinatal regions, and municipal jurisdictions, is an important feature of IPODM. In a sense IPODM is a tool for community diagnosis. In some cases the diagnosis results in the development of medical programs for specifically targeted populations, in other cases the diagnosis (that is the detailed inspection of health outcome data by small area) prompts further epidemiologic investigation to determine why specific health outcomes are so adverse in specific locations.

\section{The IPODM system}

The IPODM system was designed for a mainframe computer and an IBM-CMS [9] environment. Functionally, the system has three major components. The first consists of a library of SAS programs and macro instruction sets that create system databases (in SAS) from the 1980 United States census summary type file 1 (STF1), from the 1980 Unites States census summary tape file 3 (STF3), and from the 1982 and 1984 all California linked birth death tape (LBD). In order to merge census tract based vital statistics data with zip code based linked birth data (LBD) IPODM developed a file of zip code census tract correspondences [3]. This file was developed by identifying the census tract composition of each zip code in California's tracted counties and allowed us to build STF1 and STF3 census tract veriables up to the zip code geographic level.

As shown in figure 1, five SAS databases are created at the zip code and five SAS databases are created at the census tract level. Documentation is provided that enables one to read and then incorporate new variables from STF1 and STF3 or linked birth death tape into the existing SAS databases and also to incorporate entirely novel databases such as hospital discharge diagnosis into the system.

In order to compare key variables at either the census tract or zip code level IPODM also has "standard" programs that determine a variable's sextile cut points based on the entire California database. The databases containing these cut points is called a format library as the cut points are used to create the shading intervals (formats) when a variable is mapped. 


\section{DATA SOURCES}

1980 U.S. Census summary tape files (STF) 1 and 3 1982, 1983 California linked birth/death file All California Zipcode/Census correspondence file

IPODM SAS Library for data base construction

SAS DATA BASES

\begin{tabular}{|c|c|}
\hline ZIP CODE AREAS & CENSUS TRACTS \\
\hline STF 1 & STF 1 \\
STF 3 & STF 3 \\
LBD 82 & LBD 82 \\
LBD 83 & LBD 83 \\
LBD 82 \& 83 & LBD 82 \& 83 \\
\hline sextile formats & sextile formats \\
\hline
\end{tabular}

IPODM interactive system

USER DATA SETS

Figure 1. The improved pregnancy outcome data management system's (IPODM) database configuration.

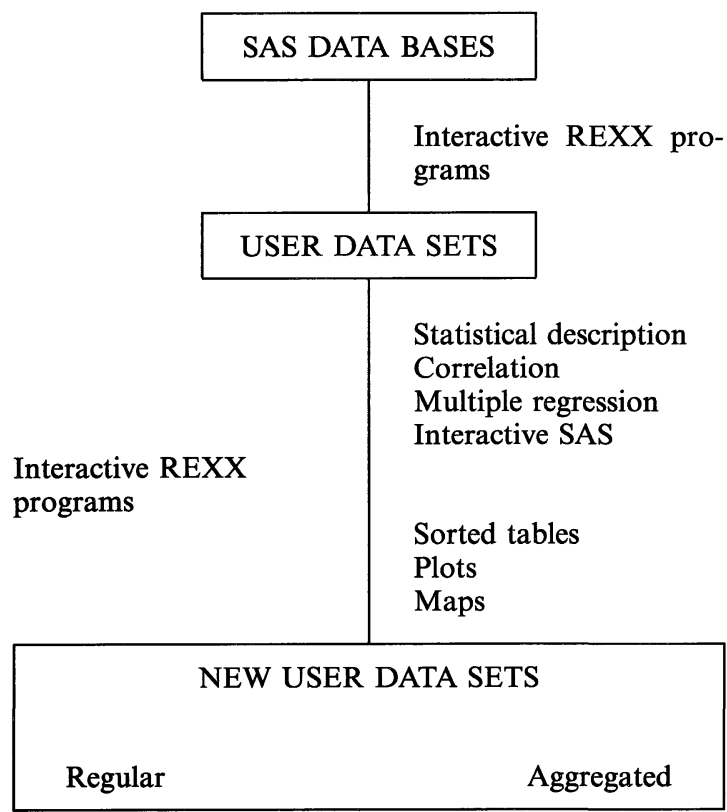

Figure 2. A schematic overview of the IPODM system.
IPODM's second major component creates user datasets from the ten SAS databases, and provides utilities to analyze and display these datasets (figure 2).

The programs to accomplish this are written in CMS REXX [2], a standard command interpreter only available with CMS. These REXX programs create an interactive protocol that allows a user with little or no computer experience to rapidly build user data bases and to perform basic analysis such as descriptive statistics, correlations, and multiple regression.

In addition to these procedures one can also enter interactive SAS from IPODM and the more experienced user can perform a variety of sophisticated procedures such as factor and cluster analysis. By following a series of interactive prompts the user dataset can be readily displayed as a sorted table, graphed as a plot, or mapped* (figure 3).

IPODM's interactive format greatly facilitates building user datasets and performing analysis. In order to build a dataset listing every zip code in a county, requires answering a series of seventeen questions. At any point in this process one can access help screens for further assistance. Table I is a facsimile of the first eleven questions in order to illustrate our approach. Question numbers and " " surrounding the user's response have been added to the facsimile for the sake of clarity.

The third component of the system allows one to modify old user data sets in order to create new user datasets. The new dataset may include only a subset of the variables that were included in the original set. The new dataset may also be trimmed limiting observations to include only those zip codes or census tracts that exceed a certain value of any variable in the database. For example a dataset characterizing areas with high levels of low birthweight could be trimmed so as to include only those zip codes with a percentage of low birthweight in excess of $7.5 \%$. The new dataset may also aggregate the individual areas of the old dataset [zips or census tracts] into larger geographic units.

* In order to map a file of coordinates must be made available to the system. IPODM uses files purchased from Geographic Data Technology, Inc. Lyme, New Hampshire. 


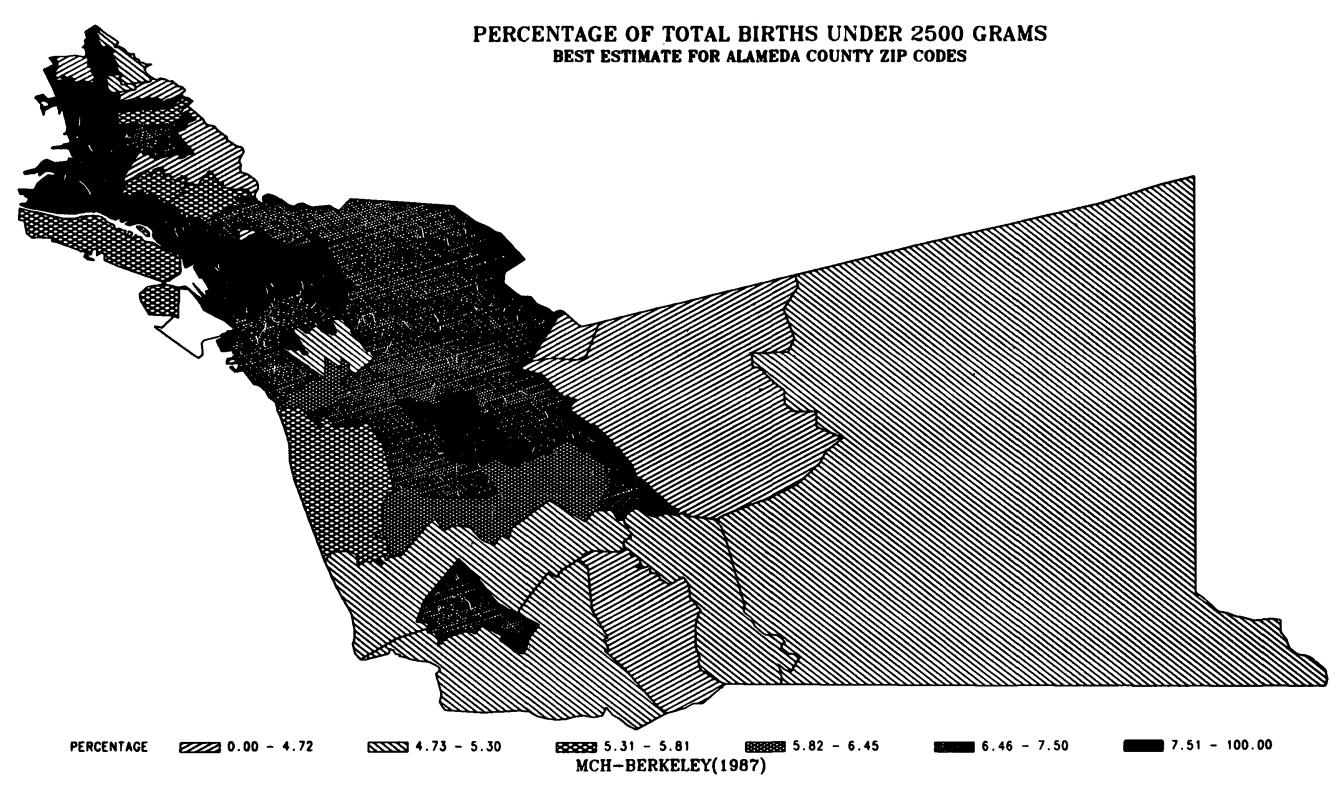

Figure 3. An IPODM map identifying the extent of low birth weight in a California county by zip code area. The six levels of low birth weight correspond to the sextile cutpoint values based on all of California's zip codes.

\section{Aggregation}

The basic geographic unit for the IPODM system is the census tract (or the zip code). A regular dataset consists solely of these basic units and provides important information for health planning purposes. Figure 3 for example is a map derived from a regular dataset. Of even greater importance to health planners is the ability to determine the sociodemographic composition, health need, and pregnancy outcome in defined geographic areas. For example a community based or perinatal system based health planner may want to profile data for all of East, West, and Central county in order to decide where to establish a prenatal clinic for high risk patients, may want data on teen pregnancy for every school district in the county (in order to select the school district that could most benefit from establishing a teen family life program), may want data on the number of Hispanic births in each visiting nurse catchment area (in order to more effectively deploy Spanish-speaking visiting nurses), etc. IPODM allows one to easily build aggregated user datasets by specifying the variables of interest, the number of aggregates to be formed, and the "code numbers" of the zip codes of census tracts that make up each aggregate. Using the IPODM utility "areas" one can easily define and store geographic specifications (for example, the zip codes that make up "East, West, and Central county") as area definitions.

The data in table II was taken directly from an aggregated IPODM dataset in order to illustrate IPODM's small area analysis capability. In this example a target area consisting of nine contiguous zip codes has been proposed as a site for an improved pregnancy outcome project. The proposal was based on the clinical impression of a high degree of poverty and poor pregnancy outcome in the target area. The purpose of the analysis was to provide a quantitative estimate of this clinical impression by comparing poverty and pregnancy outcome in the target area and the remainder of the county. From table II we see that the proposed target area has a large minority population, a median family income that is half that of the rest of the county and poverty indicators that are at least two and a half times greater than the remainder of the county. With respect to perinatal indicators there are twice as many births to young teens, to mothers with parity greater than 6 , and to mothers with only third trimester or no prenatal care. The percent low birth weight, neonatal mortality, and perinatal mortality rates are dramatically higher in the proposed target area. 
Table I. Building a regular data set with IPODM's interactive format

A facsimile of the first 11 of the 17 required questions

1. Tract or Zipcode level data set? (T or Z) " $Z$ "

2. Create a new data set? ( $\mathrm{Y}, \mathrm{N}$, or $\mathrm{L}$ where $\mathrm{L}$ means list all existing data sets) "Y"

3. Make an aggregated data set? ( $\mathrm{Y}$ or $\mathrm{N})$ "N"

4. Make a NEW data set from the standard data sets or MODIFY one of your own data sets? (NEW or MODIFY) "NEW"

5. Name of new data set? (maximum of 8 characters) "SANTACRUZ"

6. Do you want to select for particular counties for this data set? ( $\mathrm{Y}$ or $\mathrm{N})$ "Y"

7. List FIPS codes of counties you want on the next line (dash ok) "87"

8. Select particular observations by ZIPCODE number? ( $\mathrm{Y}$ or $\mathrm{N})$

"N"

9. Use predefined variable sets (made earlier by going thru VARIABLE program) for making new data set? $(\mathrm{Y}$ or $\mathrm{N})$ "N"

10. At this point you have three choices.

If you want variables from the Perinatal Needs Assessment Inventory type $P$

If you want variables from the Congenital Malformation Inventory type C If you prefer to choose variables yourself type I Type HELP and look into DATASET for more info or type response to the above question "I"

11. Do you want STF1 variables? ( $\mathrm{Y}$ or $\mathrm{N}$ ) "Y"

\section{Variables}

IPODM provides the health manager with variables derived from the 1980 census, and from the 1982 and 1983 all California linked birth death tape. The census variables include information that are commonly used by health planners such as age, race, sex, marital status, household type and relationship, education, labor force status, income, poverty status, housing quality, and ov-
Table II. Comparison of a proposed high need target area and the remainder of a county

\begin{tabular}{lcc}
\hline $\begin{array}{l}\text { Population } \\
\text { \% Black }\end{array}$ & 129,892 & 973,700 \\
\% Hispanic & $66 \%$ & $12 \%$ \\
$\begin{array}{l}\text { Median family income } \\
\text { \% Households on public }\end{array}$ & $12 \%$ & $9 \%$ \\
$\begin{array}{l}\text { assistance } \\
\text { \% Children in poverty }\end{array}$ & $26.3 \%$ & 824,217 \\
\% Female head of households & $38.9 \%$ & $10.5 \%$ \\
with children & $15.3 \%$ & $6.8 \%$ \\
\hline $\begin{array}{l}\text { Birth } \\
\text { \% Births to mothers }\end{array}$ & 5,660 & 31,177 \\
less than 17 & $3.9 \%$ & $1.5 \%$ \\
\% Parity greater than 6 & $3.3 \%$ & $1.3 \%$ \\
\% No or only third trimester & $4.3 \%$ & $2.3 \%$ \\
care & & \\
\% LBW & $10.9 \%$ & $6.3 \%$ \\
Neonatal deaths & $7.6 / 1000$ & $4.4 / 1000$ \\
Perinatal deaths & $14 / 1000$ & $9.7 / 1000$ \\
\hline
\end{tabular}

ercrowding. The linked birth death certificate (LBD) variables include data on outcomes such as complications of pregnancy, low birthweight, malformations, and mortality; on risks such as age, marital status and ethnicity; and on program indicators such as inadequate prenatal care and short interpregnancy interval. These are available for the entire population, for specific racial and ethnic subpopulations, and also for young teenagers. In all, over 500 variables are available to describe sociodemographic profile and perinatal health. With so much available how does one get started? How does one begin the process of converting data into information? The perinatal needs assessment inventory (PNI) is our first approach in providing an efficient starting point. The PNI consists of 28 variables that are commonly cited as key sociodemographic indicators, and specific indicators of perinatal risk, outcome, and program need (table III). To build a dataset including these 28 variables one simply requests " $P$ " (question 10 , table II).

Conceptually the PNI is a multivariable inventory organized with respect to the specific usefulness of each class of variables. However, specific health planning projects may require different sets of variables. The IPODM utility "variables" allows one to define profiles consisting of any combination of variables, name this combination, and store it for future use. For example, a profile called 
Table III. Perinatal needs assessment inventory (PNI)

1. Ethnicity

Total population

Whites

Blacks

Spanish

Asian/Pacific Islanders

2. Sociodemographic factors associated with pregnancy outcome

Females 15-44

Female head of household with children

Total did not complete high school

More than 1.01 persons per room

3. Poverty indicators

Households with public assistance

Median family income

Number of persons below $75 \%$ poverty

Number of persons below $200 \%$ poverty

Number of children $0-17$ in poverty

4. Perinatal risk

Non-marital births

Black mothers

Mothers born in Mexico

Prenatal complications

5. Program indicators

Inadequate prenatal care

Mother less than 17

Short birth interval

Parity greater than 6

6. Perinatal outcome

Total number of births

Complicated labor and delivery

Low birth weight births

Fetal deaths

Neonatal deaths

Perinatal deaths

"Mexican born" might contain variables selected from the IPODM birth certificate variables that are specific to the pregnancies of Mexican-born mothers such as their total births, percent inadequate prenatal care, percent short interpregnancy interval, percent low birth weight, perinatal mortality rate, etc.

\footnotetext{
Abstract

The decentralization of health management requires that appropriate tools be developed for decision support at the local level. The Improved Pregnancy Outcome Data Management System (IPODM) was designed to enable
}

Once defined, the "profile" can be used to rapidly create user datasets without having to type in the names of all the variables. This utility is especially helpful for comparing the service areas of several project sites.

\section{Comment}

The purpose of this paper is to describe the improved pregnancy outcome data management (IPODM) system developed at the University of California Berkeley for the State of California's Maternal and Child Health Branch. IPODM is a tool to facilitate health management at the local level. It is the ease with which complex data analysis projects can be rapidly performed by a health planner with minimal mainframe computer experience that gives IPODM its power as a health planning and evaluation tool. As funds to improve perinatal welfare become increasingly more limited, the need for information on which to assess the adequacy of population based pregnancy outcome and on which to base program development and allocation decisions emerges as an important priority. Such decisions are best made by those managers, planners, and practitioners who possess local knowledge. Unfortunately, the technical training, database access, and powerful computing systems which can so greatly support these decisions are usually not available locally. IPODM was designed to overcome these limitations and meet the requirements of local in-house perinatal health management. It is a unique example of an interactive small area decision support system with sociodemographic and perinatal databases in place which is accessible by telephone from on-site locations. While primarily designed to facilitate health planning and evaluation at the local level, the system can also provide the central health planner with a quantitative description of the perinatal need and pregnancy outcome in specific local areas - information that can be used to enhance the central review of local programmatic requests.

health managers and physicians with little computer experience to access over 500 variables derived from United States Census and California Vital Statistics sources. Using an interactive format one can create 
datasets describing the sociodemographic composition and perinatal outcome of individuals residing in individual census tracts (or zip codes) and in aggregates of these basic units such as neighborhoods, health catchment areas, or municipal districts. IPODM allows one to analyze this information in terms of tables, plots, maps, and basic statistical procedures using an interactive format. This paper describes the system designed for the State of California and the principles that guided the design.

Keywords: Census tract, computerized analysis, health management, improved perinatal outcome, needs assessment, small area analysis, zip code.

\section{Zusammenfassung}

Verbesserung der perinatalen Ergebnisse durch Datenverarbeitung: Über den Entwurf eines Verarbeitungssystems für kleinere regionale Bereiche

Der optimale Einsatz von Hilfsquellen zur Verbesserung der perinatalen Gesundheit erfordert Informationen, auf die sich Gesundheitsplanung und Entscheidungsgremien stützen können, und die zur Berechnung der aus diesen Entscheidungen resultierenden Ergebnisse herangezogen werden können.

Das „Datenverarbeitungssystem für verbesserte perinatale Ergebnisse (IPODM)“ wurde entwickelt vom Maternal and Child Health Program, University of California - Berkeley, School of Public Health, unter der Schirmherrschaft des State of California Maternal and Child Health Branch.

IPODM erleichtert die Datenverarbeitung für regionale Bereiche und bietet den Ärzten und Wissenschaftlern die Möglichkeit zur Analyse von Daten aus Volkszählungen und von Perinataldaten, die auf standesamtlichen Urkunden basieren. Mehr als 500 Variable stehen zur Beschreibung von soziodemographischem Profil und perinataler Gesundheit zur Verfügung. Ausgehend vom jeweiligen Zählbezirk und/oder der Postleitzahl können dann die Daten übernommen und zu einem größeren geographischen Gebiet ergänzt werden. Sowohl auf regionaler als auch auf Landesebene erleichtert das System die Auswertung der perinatalen Anforderungen und Ergebnisse, die volks-, soziodemographisch, geographisch und altersbedingt sind.

\section{Das IPODM System:}

Beim Entwurf des IPODM wurden 5 Schlüsselspezifikationen entwickelt: das System sollte 1) interaktiiv sein, 2) auf Standardelementen und Standardausstattung basieren, 3) über Modem anwählbar sein, 4) leicht ausbaubar sein und 5) die leichte Erweiterung um Postleitzahlen und Zählbezirkeinheiten zu größeren geographischen Einheiten gestatten. IPODM wurde für eine IBM-CMSAusstattung entwickelt, die REXX für interaktive Kom- mandostrukturen und SAS zum Aufbau und zur Änderung der Datenbank benutzt. Auf die Datenbank kann über Telefon per Terminal oder PC zugegriffen werden. In funktioneller Hinsicht verfügt IPODM über 3 Hauptkomponenten. Die erste besteht aus einer Bibliothek von SAS Programmen und Makro-Befehlssätzen, die die Magnetbänder der System-Datenbank der Volkszählung in den Vereinigten Staaten 1980 (in SAS) und die der aller Todesfälle bei der Geburt in ganz Kalifornien (1982-1984) begründeten.

Die zweite Komponente erstellt Datensätze für Benutzer und stellt interaktive Hilfsprogramme zur Analyse und Bildschirmausgabe dieser Daten zur Verfügung. IPODMs interaktives Format erleichtert in hohem Maße den Aufbau von Benutzerdatensätzen. Z. B. erfordert der Aufbau eines Datensatzes, der sämtliche Postleitzahlen in einem Land ausgibt, die Beantwortung von 17 Fragen. Darüber hinaus ermöglicht das System die Spezifikation verschiedener Profile oder Variablenkombinationen zur Untersuchung spezifischer Fragestellungen. Das „Verzeichnis über perinatologische Bedarfsplanung (PNI)“ ist ein Basisdatensatz, der im System eingebaut ist und aus 28 Variablen besteht, die gemeinhin als soziodemographische Schlüsselindikatoren und als spezifische Indikatoren für perinatales Risiko, Ergebnis und Programmanforderungen bezeichnet werden.

Die dritte Komponente gestattet die Modifikation alter Benutzerdatensätze zur Erstellung neuer Benutzerdatensätze. Der neue Datensatz kann eine Untermenge sein, oder er kann die Postleitzahl oder die Gebiete der Erhebung der alten Datensätze in größere geographische Einheiten integrieren, wie z. B. Gebiete der Krankenversorgung, Stadtbezirke und Landkreise.

IPODM ist, kurz gesagt, ein einzigartiges Beispiel für ein interaktives, für lokale Bereiche konzipiertes Programmsystem für Entscheidungshilfen, das über das örtliche Telefonnetz erreichbar ist. Es erlaubt die Darstellung der Daten in einer Art und Weise, die unser Verständnis der Probleme verbessern kann und die eine Hilfestellung zur Wahl der Alternativen anbietet.

Schlüsselwörter: Bedarfsplanung, Computeranalyse, Gesundheitswesen, Lokalanalyse, Postleitzahl, Verbesserte perinatale Ergebnisse, Zählbezirk.

\section{Résumé}

Amélioration du devenir périnatal par la prise en charge des données: projet d'un système d'analyse de petites zones L'utilisation optimale des ressources pour améliorer la santé néonatale nécessite une information sur laquelle on peut fonder un programme de santé, des décisions d'allocation et une information qui peut être utilisée 
pour évaluer l'issue de ces décisions. Le systême de prise en charge des données pour améliorer le devenir périnatal (IPODM) a été développé par le programme de santé maternelle et infantile à l'université de Californie - Berkeley, école de santé publique sous contrat avec service de santé maternelle et infantile de l'état de $\mathrm{Ca}$ lifornie.

L'IPODM a été projeté pour faciliter l'analyse de petites zones et pour permettre aux médecins et aux personnels de santé locaux d'analyser les recensements fondés sur les données socio-démographieques et les statistiques vitales fondées sur les données périnatales. Plus de 500 variables sont disponibles pour décrire le profil sociodémographique et la santé périnatale. Commençant au niveau des fiches de recensement et/ou du code Zip, les données peuvent ensuite être rassemblées au sein de zones géographiques plus importantes. Le systême facilite l'analyse des besoins périnataux et du devenir en fonction de l'ethnie, de l'état sociodémographique, de l'âge et de la géographie, tant au niveau local, qu'au niveau d'un état.

Le systême IPODM: En projetant l'IPODM nous avons développé cinq clés spécifiques. Le systême doit être 1) interactif, 2) fondé sur des éléments standards et un environnement opératoire, 3) accessible par Modem, 4) de diffusion commode, et 5) autorisant l'assemblage aisé des codes Zip de base et des unités des fiches de recensement au sein de zones géographiques plus vastes. L'IPODM a été conçu pour un environment IBM-CMS en se servant de REXX comme structure de commande interactive et de SAS pour entrer et manipuler les bases de données. Il peut être joint par téléphone au moyen d'un terminal ou d'un ordinateur personel. Sur le plan fonctionnel, l'IPODM a trois composantes majeures. La première est une librairie de programmes SAS et d'en- sembles de macro-instructions qui créent les bases de données (dans SAS) à partir des bandes du recensement des Etats-Unis de 1980 et des bandes (LBD) de morts à la naissance pour l'ensemble de la Californie de 1982 à 1984. La seconde crée des ensembles de données utiles et assure des facilités interactives pour analyser et afficher ces ensembles de données. Le format interactif de l'IPODM facilite grandement la réalisation des ensembles de données utiles. Par exemple, réaliser un ensemble de données comprenant tous les codes Zip d'un comté nécessite la réponse à dix sept questions. Le systême permet également à quelqu'un de préciser des provils divers ou des combinaissons de variables pour examiner des résultats spécifiques.

L'inventaire d'améliorations des besoins périnataux (PNI) est un profil qui a été réalisé à l'intérieur du systême et qui consiste en 28 variables qui sont couramment citées telles que les indicateurs sociodémographiques et les indicateurs spécifiques de risque périnatal, de devenir, de besoin de programme. La troisième composante permet à l'utilisateur de modifier les ensembles de données anciennes afin de créer des ensembles de données pour un nouvel usage. L'ensemble de nouvelles données peut être un sous-ensemble. On peut assembler le code Zip ou les aires des fiches de recensement des ensembles de données anciennes dans des unités géographiques plus vastes que les zones de service de santé, les municipalités, les régions.

En résumé, l'IPODM est un exemple unique de systême interactif d'aide à la décision pour de petites zones, par téléphone à partir du terrain. Il assure une méthodologie pour manipuler, analyser et afficher ces données dans une optique qui peut améliorer notre compréhension des problèmes et des solutions, ainsi que l'utilité relative des choix que nous envisageons.

Mots-clés: Amélioration du devenir périnatal, analyse de petites zones, analyse informatisée, code Zip, estimation des besoins, fiche de recensement, prise en charge de santé.

Acknowledgements: The research project was supported by the State of California Department of Health Services, Maternal and Child Health Branch, under Contracts \#84-84088 and \#85-86955.

The authors would like to acknowledge Manie Chen, Ellen Liebman, Frank Many, and CAROL NiCKERSON for their work in the initial design of the IPODM system and to thank Ms. CONNIE GEE for her important assistance in the preparation of the project reports and this manuscript.

\section{References}

[1] Brackstone GJ: Small area data: Policy issues and technical challenges. In: PlateK R, JNK RaO, CE SARNDAL, MP SINGH (eds): Small Area Statistics, pp. 3. John Wiley and Sond, Inc. New York 1987

[2] Cowlishaw MF: The REXX language: A practical approach to programming, Prentice Hall, Englewood Cliffs, N. J. 1985
[3] Gould JB, E Liebman, A White, M Lucero, C Nickerson, F MANY: 1980 census tract composition of California zip codes guide. Improved Perinatal Outcome Data Management Project, Maternal and Child Health Program, School of Public Health, University of California, Berkeley, prepared under contract \#84-84088 to Maternal and Child Health Branch, California Department of Health Services, June 1985 
[4] INVITED PAPERS TO THE DATA USE CONFERENCE ON SMALl AREA STATISTICS. AUGUST 29-31, 1984, SNOWBIRD, Utah, U.S. Department of Health aND Human Services, Public Health Service, NaTIONAl Center for Health Statistics

[5] Miller CA: Infant mortality in the U. S., Scientific American, 253(1) (1985) 31

[6] SAS user's guide, Cary North Carolina, SAS Institute, Inc., 1982

[7] SHELDON T: Introducing PC-DOS and MS-DOS: A guide for beginning and advanced techniques. McGraw-Hill, New York 1985

[8] Trachtenderg A, L Gardner, JB Gould, S HUTCHISON: Building an integrated community health information base. In: NUTTING PA (ed):
Community-Oriented Primary Care: From Principle to Practice, pp 109. U.S. Department of Health and Human Services, Public Health Service, HRSA Publication No. HRS-A-PE 86-1, 1987

[9] VM/system product: CMS primer, Release 3, IBM Corporation, New York, SC24-5236-1, September 1983

[10] WHITE KERR L: Information for health care: An epidemiological perspective. Inquiry 17 (1980) 17

Jeffrey B. Gould, M. D., M. P. H.

Associate Professor

Maternal and Child Health Program

School of Public Health

University of California

Berkeley, CA. 94720, U. S. A. 